\title{
VISUALISASI TAGAR \\ DALAM MEDIA SOSIAL INSTAGRAM (Analisis Wacana Kritis Model Norman Fairclough)
}

\author{
Nikodemus Goratama Nuswantara
}

\author{
Program Studi Desain Komunikasi Visual \\ Fakultas Seni Rupa, Institut Seni Indonesia Yogyakarta \\ nikodemusgo@gmail.com
}

\begin{abstract}
Hastag on Instagram is a form of sign system in cyberspace that serves as a medium of the messages. Hastag on Instagram is used as a bookmark for archiving, managing, and searching information online. Along with its progress, hastag is not only used to archive an information but also includes a message, and ideas of social phenomena.The Message, and ideas contained in this hastag then become a discourse in Instagram. The discourse is not only formed from the text verbally, but also contained in the visual form. The hastag becomes a discourse because it has meaning and effect in the real world and also make a social movement in social media. Thisshould be interesting because each user can interpret their own ideas related to the hastag, and other users as consumers can also interpret the text in the hastag in various ways.This undergraduate thesis was analyzed on a \#kamitidakatut sample uploaded by @jokowi and @najwashihab Instagram account. Hastag Pekan Pancasila (\#pekanpancasila) uploaded by @jokowi and @itsrossa910 Instagram account. And \#rayakanderbedaan uploaded by @ciacia_saratasha and @klkkln Instagram account. This sample was analyzed using critical discourse analysis by Norman Fairclough. From these analyzes, we find some conclusions related to the dimensions of the text, the practice of discourse, and social practices that form the hastags on Instagram. The final result of this undergraduate thesis concludes that the hastag and visualization on Instagram emerged as a trend in responding to various issues, social phenomena and causing a new social movement in society. This is useful for research who want to pursue and add insights related to cyberculture and insight about the role of hastag in social media.
\end{abstract}

Keywords: hastag, sign system, social media, instagram, critical discourse analysis

\section{PENDAHULUAN}

Pesatnya perkembangan teknologi informasi dan komunikasi menyebabkan masyarakat semakin mudah dalam menerima maupun menyampaikan informasi yang ingin disampaikan. Dengan berbagai kemudahan yang ada, komunikasi pada saat ini tidak harus dilakukan secara langsung bertatap muka (face-to-face). Kehadiran teknologi pengumpulan data (storage) yang terkoneksi ke dalam jaringan maupun bahasa komputer, memungkinkan individu di dalam jaringan tersebut dapat mengakses informasi kapan pun dan di mana pun. Komunikasi tersebut termasuk ke dalam komunikasi termediasi komputer. Berbeda hal nya dengan komunikasi secara langsung, pola komunikasi termediasi komputer seperti yang dikemukakan oleh Rulli Nasrullah dalam bukunya yang berjudul Komunikasi Antarbudaya di Era Budaya Siber (2010) ini terjadi berdasarkan teks semata. Dalam 
prosesnya komunikasi tersebut dapat terjadi melalui perantara, salah satunya sambungan internet.

Internet pada awal kemunculannya merupakan sebuah teknologi yang hanya menghubungkan antarkomputer dan digunakan untuk keperluan militer Amerika Serikat pada tahun 1969. Lambat laun desakan kepentingan individu maupun golongan menyebabkan internet dibutuhkan untuk digunakan masyarakat secara luas. Internet yang pada mulanya hanyalah teknologi untuk menghubungkan antarkomputer semata, berevolusi menjadi sebuah medium interaktif antara dua media atau lebih yang difasilitasi oleh komputer. Karena bentuk interaksi yang ada di dalam internet memiliki hubungan dengan kehidupan sosial, maka seiring perkembangannya internet saat ini dipandang sebagai sebuah budaya yang di dalamnya terkandung fenomena-fenomena sosial seperti yang terjadi dalam interaksi antarindividu secara langsung.

Berdasarkan data yang dilansir oleh Gareta (2016) dalam laman antaranews.com, saat ini $47 \%$ dari total seluruh populasi dunia telah terkoneksi dengan internet. Melalui internet ini, milyaran individu dari seluruh dunia dapat berinteraksi dan membentuk suatu relasi dalam ruang virtual. Sehingga proses komunikasi di dalam internet tidak hanya melibatkan antarpersonal saja, melainkan sudah melibatkan individu yang lebih luas.

Salah satu proses komunikasi antarindividu dalam internet tersebut dapat terjalin melalui media sosial. Media sosial merupakan medium di internet yang memungkinkan pengguna untuk merepresentasikan dirinya, berinteraksi, berbagi informasi, dan berkomunikasi dengan pengguna lain dalam ruang virtual. Melalui media sosial, masyarakat internet dapat bersosialisasi dengan pengguna lain hingga mengakses berbagai informasi dengan cepat dan mudah. Kemudahan mengakses informasi dalam media sosial ini, salah satunya dapat dilakukan dengan menggunakan tanda pagar atau disingkat tagar (\#).

Tagar dalam media sosial merupakan salah satu bentuk tanda (sign) dalam ruang virtual yang berfungsi sebagai medium pembawa pesan. Pada dasarnya maksud seseorang berkomunikasi bukan hanya mengirimkan pesan saja, namun juga hendak menanamkan makna tertentu dalam pikiran penerima. Tanda dalam komunikasi menjadi sangat mendasar dalam menciptakan maknamakna tertentu, dan dalam hal ini adalah tanda pagar yang dihadirkan dalam media sosial. Tagar pertama kali digunakan sebagai sebuah penanda dalam media sosial pada tahun 2003 dengan kehadiran situs Delicious 
(del.icio.us). Perkembangan penggunaan tagar ini kemudian menjadi semakin populer sejak tanggal 1 Juni 2009 saat Twitter secara resmi menautkan semua kata yang didahului tanda pagar (\#) kedalam tautan lain yang juga menggunakan tagar yang sama. Sejak saat itu lah, tagar berfungsi sebagai suatu sign system dalam perkembangan budaya siber.

Tagar dalam media sosial ini digunakan sebagai sebuah penanda untuk menyimpan, mengelola, dan mencari informasi atau berita tertentu secara online. Informasi pada tagar bukanlah informasi yang utuh. Artinya, pengguna hanya disediakan informasi berupa teks, foto, ataupun video secara singkat sebagai pengantar yang kemudian pengguna akan diarahkan pada tautan sumber informasi itu berada.

Saat ini tagar sering digunakan pengguna media sosial sebagai alat propaganda pada berbagai isu-isu sosial. Salah satu contohnya adalah tagar \#kamitidaktakut yang muncul sebagai respon pengguna media sosial terhadap peristiwa pengeboman dan penembakan yang terjadi di sekitar Gedung Sarinah, Thamrin, Jakarta Pusat pada tanggal 14 Januari 2016 lalu. Tagar \#kamitidaktakut ini digunakan pengguna media sosial sebagai bentuk representasi masyarakat Indonesia yang tidak takut akan segala bentuk aksi terorisme dan radikalisme. Seperti yang diungkapkan
Mahmud (2016) dalam laman kompasiana.com, tagar \#kamitidaktakut ini merupakan respon positif masyarakat terhadap ajakan presiden Jokowi yang mengecam aksi teroris dan mengajak masyarakat tidak takut dengan tindakan teror. Ajakan Presiden ini ternyata menuai respon dari pengguna media sosial untuk mengajak masyarakat berani melawan aksi terorisme melalui tagar \#kamitidaktakut. Walaupun tagar ini hanya disampaikan melalui media sosial, namun efek yang ditimbulkan memiliki makna yang dapat menumbuhkan sikap dan aksi solidaritas.

Selain tagar \#kamitidaktakut, masih banyak ragam tagar yang muncul sebagai respon pengguna media sosial terhadap isuisu sosial yang sedang terjadi. Sebut saja seperti tagar \#menolaklupa yang merupakan bentuk respon masyarakat internet terhadap kasus Marsinah, Wiji Thukul, pembunuhan Munir, hingga kasus kerusuhan Mei 1998 yang dinilai tidak tuntas dalam proses penyidikan. Ada pula \#pekanpancasila yang digalakkan oleh pemerintah dalam peringatan Hari Kelahiran Pancasila yang diperingati setiap tanggal 1 Juni. Tagar \#rayakanperbedaan yang mengajak masyarakat untuk bersama-sama merayakan perbedaan suku, ras, dan agama di tengah maraknya isu SARA yang berkembang pada medio pertengahan tahun 2017 , dan berbagai 
tagar lain yang juga merespon isu-isu sosial yang sedang terjadi di Indonesia. Tagar-tagar tersebut dapat kita jumpai dalam berbagai media sosial seperti Facebook, Twitter, Instagram, dsb, yang masing-masing media sosial tersebut memiliki ciri khas tersendiri dalam penyajian bentuk tagar yang dapat diproduksi maupun diakses oleh para pengguna.

Penelitian ini memfokuskan pada tagar yang terjalin melalui media sosial Instagram. Instagram merupakan sebuah aplikasiberbagi foto/videobuatan Burbn.Inc pada tahun 2010 yang memungkinkan pengguna mengambil foto/video, dan membagikannya ke berbagai layanan jejaring sosiallain, termasuk milik Instagram sendiri. Tagar dalam media sosial Instagram digunakan sebagai tanda dalam judul (caption) foto/video yang diunggah oleh pengguna. Penggunaan tagar-tagar tersebut dalam judul (caption) foto/video berkaitan dengan teks yang ada didalamnya. Teks dalam judul (caption) foto/video juga memiliki hubungan dengan konten foto/video yang diunggah oleh pengguna. Pengguna sebagai produsen selain mengunggah foto/video juga dapat menuliskan atau menuangkan pesan, ide, maupun gagasan apa saja yang dikehendakinya melalui tagar, sehingga dapat diakses oleh pengguna lain yang mencari informasi melalui tagar yang sama pada kolom pencarian (tags).
Pesan, ide, dan gagasan yang tertuang dalam bentuk tagar inilah yang kemudian menjadi sebuah wacana dalam media sosial Instagram. Tagar tersebut menjadi sebuah wacana karena memiliki makna dan efek dalam dunia nyata. Hal ini menjadi menarik karena setiap pengguna dapat menafsirkan sendiri gagasannya terkait dengan tagar yang digunakan, dan pengguna lain sebagai konsumen juga dapat memaknai teks dalam tagar secara beragam. Proses produksi dan konsumsi teks pada tagar yang kemudian memunculkan sebuah gerakan sosial pada Instagram tersebut kemudian dianalisis menggunakan empat langkah analisis data yang dikembangkan oleh Fairclough yang bertujuan untuk menjawab hubungan antara pengaruh pemikiran kritis dan praktik sosial dimaknai pada tagar dalam media sosial Instagram. Ke-khas-an penggunaan analisis wacana kritis tersebut terletak pada tiga dimensi, yakni, analisis teks, praktik kewacanaan, dan bagaimana praktik sosial terbentuk dalam proses produksi dan konsumsi teks. Melalui analisis wacana kritis, kita dapat membedah wacana apa yang terdapat dalam tanda pagar beserta visualisasinya dalam media sosial Instagram.

Analisis wacana kritis merupakan salah satu metode baru dalam kajian ilmu sosial dan budaya. Dalam pengertian analisis wacana kritis, perlu diuraikan terlebih dahulu 
pengertian wacana dan pengaruh pemikiran kritis terhadap analisis wacana kritis. Pada praktiknya, wacana tidak hanya dipahami sebagai studi bahasa dalam pengertian linguistik tradisional. Menurut Lull (1998: 225) wacana berarti cara objek atau ide diperbincangkan secara terbuka kepada publik sehingga menimbulkan pemahaman tertentu yang tersebar luas. Wacana dianalisis bukan hanya dengan menggambarkan aspek kebahasaan, tetapi juga menghubungkan dengan konteks. Konteks yang dimaksud adalah praktik dalam pemakaian bahasa, termasuk di dalamnya praktik kekuasaan.

Selain itu, menurut Fairclough dan Wodak dalam Eriyanto (2001: 7) analisis wacana kritis melihat wacana (pemakaian bahasa dalam tuturan dan tulisan) sebagai bentuk dari praktik sosial. Wacana digambarkan sebagai praktik sosial yang menyebabkan sebuah hubungan dialektis di antara peristiwa diskursif tertentu dengan situasi, institusi, dan struktur sosial yang membentuknya. Wacana sebagai praktik sosial dalam bentuk interaksi simbolis dapat terungkap dalam sebuah pembicaraan, tulisan, gambar, diagram, foto, film, musik, atau sumber media lain seperti poster politik dan pamflet.

Analisis wacana kritis tidak terlepas dari pengaruh pemikiran kritis yang ada di dalam konteks. Penelitian sosial ini disebut 'kritis' karena menganalisis hal-hal seperti ketidakberesan, ketidakadilan, ketidaksetaraan, diskriminasi, ataupun ketidakbebasan yang terjadi dalam masyarakat dengan mencari sumber dan sebabnya serta bentuk-bentuk perlawanan yang mungkin terjadi. Makna kritis dalam Haryatmoko (2016: 3) diterjemahkan kedalam empat bentuk analisis: pertama, menganalisis hubungan semiosis dan unsur sosial, yaitu bagaimana semiosis menentukan/mereproduksi/ mengubah hubungan kekuasaan yang tidak seimbang dan juga proses ideologisasi; kedua, hubungan itu menuntut analisis karena logika dan dinamika masyarakat tidak selalu transparan, bahkan menyesatkan; ketiga, logika dan dinamika yang dominan perlu diuji dan ditantang oleh masyarakat. Lalu disertai dengan identifikasi kemungkinan untuk mengatasinya; keempat, mengambil jarak terhadap data, meletakkan data dalam konteksnya, mengklarifikasi posisi politik partisipan, dan fokus pada refleksi diri dalam penelitian.

Melalui penjelasan di atas, dapat disimpulkan bahwa analisis wacana kritis merupakan suatu metode analisis yang mengungkap bagaimana praktik kekuasaan, berbagai kepentingan yang terjadi dalam masyarakat

dipraktikkan/direproduksi/dilawan oleh teks 
dalam konteks sosial dan politis. Penelitian ini menggunakan analisis wacana kritis untuk mempertajam dimensi pada produksi dan konsumsi teks. Adapun tiga dimensi analisis wacana kritis menurut Fairclough (1995: 98), di antaranya:

a. Teks, yaitu semua yang mengacu ke wicara, tulisan, grafik, dan kombinasinya atau semua bentuk linguistik teks (khasanah kata, gramatika, syntax, struktur metafora, retorika).

b. Praktik kewacanaan, yaitu semua bentuk produksi dan konsumsi teks. Dalam dimensi ini ada proses menghubungkan produksi dan konsumsi teks atau sudah ada interpretasi. Fokusnya diarahkan pada cara pengarang teks mengambil wacana dan genre yang ada dengan memperhatikan bagaimana hubungan kekuasaan dimainkan.

c. Praktik sosial, biasanya tertanam dalam tujuan, jaringan dan praktik budaya sosial yang luas. Dalam dimensi ini, sudah mulai masuk pemahaman intertekstual, peristiwa sosial di mana kelihatan bahwa teks dibentuk oleh dan membentuk praktik sosial.

Pandangan Fairclough terhadap wacana dan perubahan sosial didasari atas pandangannya terhadap kedudukan ideologi dalam masyarakat. Menurutnya, wacana berfungsi untuk membangun common sense atau naturalized discourse yang membentuk makna identitas, hubungan sosial dan representasi. Dalam hal inilah konsumsi terhadap teks tersebut dalam praktik kewacanaan dan praktik sosial budaya menjadi suatu kuasa yang berlangsung dalam sebuah keadaan tidak stabil yang harus senantiasa diperjuangkan untuk dipertahankan atau diubah.

Hubungan dialektik antara wacana dan praktik sosial adalah salah satu dari lima ciri analisis wacana kritis yang dikembangkan oleh Norman Fairclough. Pertama, praktikpraktik kewacanaan itu berkontribusi dalam menyusun dunia sosial. Perubahan dan reproduksi sosial budaya terjadi. Namun, fenomena sosial budaya itu tidak semuanya bersifat linguistik-kewacanaan. Kedua, wacana itu tersusun dan bersifat konstitutif. Artinya, praktik sosial itu berpengaruh terhadap wacana dan begitu juga wacana berpengaruh terhadap praktik sosial. Ketiga, bahwa bahasa itu berada dalam konteks sosialnya. Keempat, praktik kewacanaan berkontribusi terhadap hubungan kekuasaan. Kelima, analisis wacana kritis sebagai pendekatan kritis terhadap perubahan sosial dan memiliki keberpihakan terhadap kelompok-kelompok sosial tertentu.

Wacana tidak hanya ditampilkan melalui bahasa, namun juga melalui visual. Tagar dalam media sosial Instagram tidak hanya ditampilkan dalam bentuk tulisan, tetapi juga memiliki hubungan dengan 
ilustrasi gambar/foto yang diunggah oleh pengguna. Oleh sebab itu, penelitian ini perlu meninjau pada landasan teori tentang elemen visual, seperti fotografi, ilustrasi, warna, maupun typeface

\section{Tagar dalam Media Sosial Instagram}

Pada abad ke 12, tagar atau tanda pagar (\#) muncul sebagai tanda yang digunakan dalam menaikkan not setengah nada pada bidang keilmuan seni musik. Sebutan tanda pagar (\#) ini dikenal dengan sebutan 'sharp'. Pada abad ke 14, singkatan 'lb' dari kata libra masuk kedalam bahasa Inggris. Menurut praktik penulisan secara umum, 'lb' adalah sebagai aksesoris dengan garis yang ditarik melintasi huruf untuk menekankan penggunaan sebuah kontraksi. Secara perlahan ' $1 \mathrm{~b}$ ' berubah menjadi tanda \# dan disebut 'pounds'. Seiring perkembangannya, pada tahun 1960 para ilmuwan dari Bell Laboratorium menambahkan tanda \# pada papan tombol telepon guna memberikan instruksi pada sistem informasi telepon. Mereka menyebut tanda ini dengan sebutan 'oktothorpe'. Di akhir tahun 1980 sebagai tonggak awal kemajuan teknologi informasi, simbol ini mulai memiliki beragam makna dalam beragam bahasa pemrograman komputer.

Tagar dalam teori media sosial yang dikemukakan oleh Nasrullah (2015: 44) merupakan salah satu jenis dari penanda sosial atau social bookmarking. Penanda sosial atau social bookmarking bekerja untuk mengorganisasi, menyimpan, mengelola, dan mencari informasi atau berita tertentu secara online. Informasi yang diberikan di media sosial ini bukanlah informasi yang utuh. Artinya, pengguna hanya disediakan informasi berupa teks, foto, ataupun video secara singkat sebagai pengantar yang kemudian pengguna akan diarahkan pada tautan sumber informasi itu berada.

Tagar pertama kali digunakan dalam media sosial sebagai sebuah penanda sosial sejak tanggal 1 Juni 2009 saat Twitter secara resmi menautkan semua kata yang didahului tanda pagar (\#) kedalam tautan lain yang juga menggunakan tagar yang sama. Penggunaan tagar dimulai dengan menambahkan tanda '\#' diikuti dengan kata yang diinginkan tanpa menggunakan spasi (contoh: \#saya, \#sayasenang, dsb) dan secara otomatis akan menjadi sebuah tautan dan bukan tidak mungkin akan tergabung dengan pengguna lain yang pernah menggunakan tagar tersebut. Tagar telah menjadi sebuah tanda baru dalam perkembangan budaya visual. Tanda pagar '\#' yang semula berfungsi sebagai tanda yang digunakan dalam menaikkan not setengah nada pada bidang keilmuan seni musik, dewasa ini juga dimaknai sebagai tren baru 
dalam pencarian informasi dan live event tertentu pada media sosial.

Dalam media sosial Instagram pengguna menggunakan tagar sebagai sebuah tanda pada judul (caption) foto/video yang mereka unggah dengan tujuan agar postingan foto/video tersebut dapat dengan mudah dibagikan dan ditemukan oleh pengguna lain yang hendak mencari suatu topik melalui tagar yang sama. Tagar tidak memiliki batasan bahasa maupun waktu, sehingga dapat dengan mudah ditemukan baik pengguna maupun pengguna lain kapan saja selama penulisan tagar benar (tanpa spasi). Berangkat dari penjelasan penggunaan tagar tersebut, tagar dapat didefinisikan sebagai sebuah tanda dalam dunia virtual.

\section{Analisis Wacana Kritis Visualisasi Tagar}

dalam Media Sosial Instagram

A. Tagar Kami Tidak Takut (\#kamitidaktakut)

1. Teks

Dimensi teks terbentuk atas hubungan antara teks secara verbal pada judul (caption) foto dengan konten visual yang diunggah oleh pengguna. Dalam metode yang dikembangkan oleh Norman Fairclough, terdapat 3 elemen yang membentuk teks, diantaranya representasi, relasi, dan identitas.
Representasi dalam dimensi teks tertuang pada bentuk visual yang diunggah oleh pengguna pada Instagram. Bentuk visual tersebut dapat berupa karya fotografi, ilustrasi, maupun kombinasi keduanya.

Tagar kami tidak takut (\#kamitidaktakut)

merepresentasikan bentuk visual berupa aksi masyarakat yang tidak takut melawan terorisme. Tagar ini didominasi oleh karya fotografi yang menggambarkan situasi pasca aksi terorisme yang terjadi di daerah Thamrin dan Kampung Melayu, Jakarta.

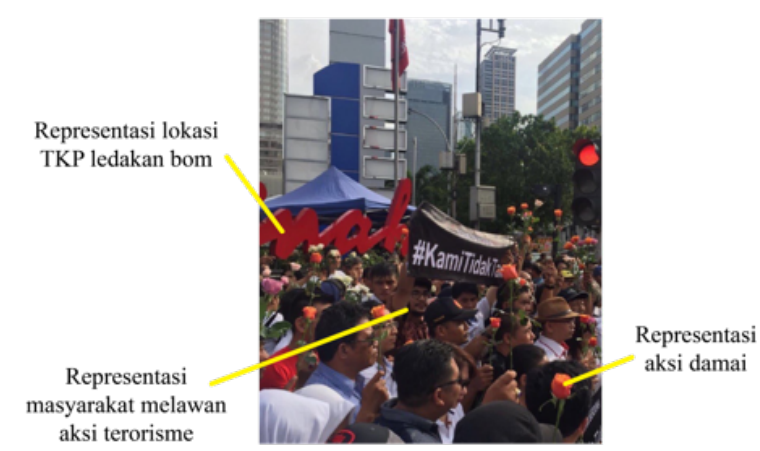

Gambar 1 Representasi visual unggahan akun @jokowi tanggal 20 Januari 2017

(Sumber: www.Instagram.com/jokowi/)

Representasi yang tergambar dalam bentuk visual tersebut memiliki hubungan/relasi dengan judul (caption) foto yang diunggah oleh 
pengguna. Sehingga bentuk keseluruhan teks tersebut memperlihatkan identitas dari pengguna tagar. Tagar kami tidak takut (\#kamitidaktakut) menunjukkan identitas penggunanya sebagai bagian dari masyarakat yang turut serta dalam menolak segala bentuk aksi terorisme.

\section{Praktik Kewacanaan}

Praktik kewacanaan tagar dalam media sosial Instagram terbentuk dari adanya produksi dan konsumsi teks yang dilakukan oleh pengguna. Dalam dimensi ini terdapat proses menghubungkan produksi dan konsumsi teks.

Produksi teks pada tagar terlihat dari banyaknya tagar yang digunakan dalam media sosial Instagram. Tahapan produksi juga memperlihatkan bagaimana wacana ditampilkan dalam bentuk visual yang diunggah dalam media sosial Instagram, yang kemudian dikaitkan dengan tagar. Produksi teks dari tagar ini mengandung sebuah wacana masyarakat internet untuk bersamasama tidak takut melawan segala bentuk terorisme. Golongan yang berusaha 'dilawan' oleh tagar ini adalah para pelaku terorisme.
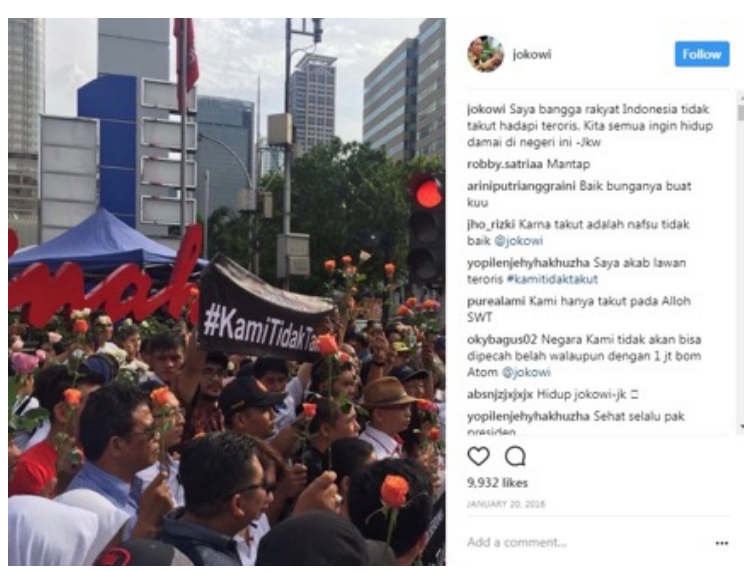

Gambar 2 Unggahan Presiden Jokowi tanggal 20 Januari 2016 terkait aksi terorisme yang terjadi di sekitar Sarinah, Jakarta Pusat (Sumber: www.Instagram.com/jokowi/)

Konsumsi teks berkaitan dengan bagaimana respon pengguna lain, selaku konsumen teks, memaknai wacana yang ditampilkan oleh produsen teks. Konsumsi teks dalam media sosial Instagram terlihat dari komentar yang diberikan pengguna lain melalui kolom komentar (comments) unggahan. Adanya bentuk konsumsi teks dari pengguna lain menunjukkan bahwa wacana yang diproduksi oleh pengguna dapat dimaknai berbeda oleh pengguna lain selaku konsumen teks.Hingga awal Juni 2017, tercatat sebanyak 179.590 unggahan yang dikaitkan/diarsipkan dengan tagar kami tidak takut (\#kamitidaktakut). 


\section{Praktik Sosial}

Pada dimensi praktik sosial memperlihatkan tujuan dari tagar sebagai bentuk respon masyarakat internet terhadap fenomena atau peristiwa yang sedang terjadi. Praktik sosial ini terbentuk melalui 3 aspek seperti situasional, institusional, dan sosial.

Aspek situasional dalam dimensi praktik sosial, memperhatikan situasi ketika teks tersebut terproduksi. Tagar kami tidak takut (\#kamitidaktakut) diproduksi oleh pengguna Instagram setelah aksi terorisme terjadi di daerah Sarinah, Thamrin, Jakarta Pusat pada tanggal 14 Januari 2016.Aspek situasional dalam dimensi praktik sosial, memperhatikan situasi ketika teks tersebut terproduksi. Tagar kami tidak takut (\#kamitidaktakut) diproduksi leh pengguna Instagram setelah aksi terorisme terjadi di daerah Sarinah, Thamrin, Jakarta Pusat pada tanggal 14 Januari 2016. Dan kemudian tagar tersebut kembali marak digunakan saat ledakan bom terjadi di daerah Kampung Melayu, Jakarta Timur, pada tanggal 24 Mei 2017.

Tagar kami tidak takut
(\#kamitidaktakut) terbentuk atas

kondisi sosial pada saat itu yang baru saja dilanda aksi terorisme. Aksi terorisme tersebut memunculkan rasa solidaritas masyarakat internet untuk bersama-sama melawan dan tidak takut terhadap segala bentuk aksi terorisme. Kondisi sosial ini lah yang kemudian membuat \#kamitidaktakut terproduksi kembali saat aksi terorisme terjadi di Kampung Melayu pada 24 Mei 2017 silam.

B. Tagar Pekan Pancasila (\#pekanpancasila) 1. Teks

Tagar Pekan Pancasila (\#pekanpancasila) merepresentasikan bentuk visual semarak perayaan Pekan Pancasila yang diselenggarakan tanggal 29 Mei sampai dengan 4 Juni 2017. Tagar ini didominasi oleh karya ilustrasi dengan dominasi warna merah putih yang secara resmi dibuat oleh pemerintah melalui Kementerian Kominfo.

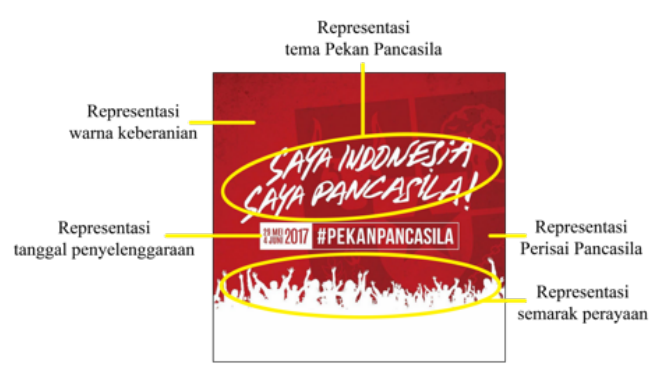

Gambar 3 Gambar 3. Representasi visual unggahan akun @jokowi tanggal 26 Mei 2017 (Sumber: www.Instagram.com/jokowi/) 


\begin{abstract}
Representasi yang tergambar dalam bentuk visual tersebut memperlihatkan nilai-nilai kebhinekaan dan semangat nasionalisme yang terkandung dalam Pancasila. Bentuk representasi visual itu memiliki hubungan/relasi dengan bentuk teks secara verbal yang terkandung dalam judul (caption) foto. Sehingga keseluruhan bentuk teks dalam tagar tersebut, memperlihatkan adanya identitas pengguna sebagai bagian dari Negara Kesatuan Republik Indonesia yang menjunjung tinggi nilai-nilai Pancasila.
\end{abstract}

\section{Praktik Kewacanaan}

Hingga awal Juni 2017, tagar ini telah diunggah sebanyak 191.072 unggahan. Produksi teks dari tagar yang secara resmi digalakkan oleh Pemerintah ini mengandung sebuah wacana untuk menggalakkan kembali nilai-nilai Pancasila dan kebhinekaan dalam kehidupan berbangsa dan bernegara. Golongan yang berusaha 'dilawan' oleh tagar ini adalah golongan masyarakat yang bertentangan dengan ideologi Pancasila.

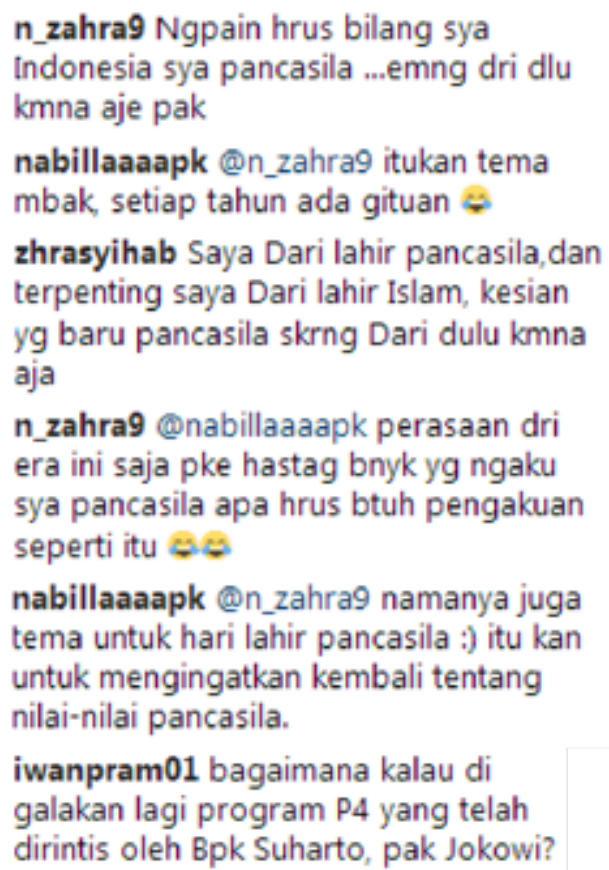

Gambar 4 Komentar pada unggahan foto akun @jokowi tanggal 26 Mei 2017 (Sumber: www.Instagram.com/jokowi/)

Pada tahap konsumsi teks, dapat terlihat pada kolom komentar yang dilakukan oleh pengguna lain dalam memaknai bentuk teks, baik verbal maupun visual, yang diunggah oleh pengguna. Sehingga akan terlihat \#pekanpancasila dapat dimaknai berbeda oleh pengguna lain.

\section{Praktik Sosial}

Aspek situasional dalam dimensi praktik sosial, memperhatikan situasi ketika teks tersebut terproduksi. Tagar Pekan Pancasila (\#pekanpancasila) diproduksi menjelang Hari Lahir Pancasila yang diperingati tanggal 1 
Juni. \#pekanpancasila terbentuk atas kondisi politik yang sedang memanas setelah Pilkada DKI Jakarta 2017. Kondisi politik ini nyatanya tidak hanya 'panas' di wilayah DKI Jakarta saja, tetapi juga telah meluas ke berbagai wilayah di Indonesia.

Hal ini dikarenakan kasus penistaan agama yang dilakukan oleh calon Gubernur nomor urut 2, Basuki Tjahaja Purnama, yang dijadikan bahan kampanye hitam oleh kelompok yang tidak bertanggungjawab. Kampanye yang bermuatan politis tersebut pada akhirnya menimbulkan berbagai isu yang berusaha merusak persatuan dan kesatuan bangsa.

Kondisi ini lah yang kemudian dimanfaatkan oleh Pemerintah untuk memunculkan tagar \#pekanpancasila sebagai salah satu bagian dari perayaan Pekan Pancasila yang dilaksanakan pada tanggal 29 Mei hingga 4 Mei 2017. Momentum yang tepat untuk mengingatkan kembali nilai-nilai Pancasila dalam kehidupan berbangsa dan bernegara melalui media sosial.

C. Tagar Rayakan Perbedaan (\#rayakanperbedaan)

1. Teks
Tagar rayakan perbedaan (\#rayakanperbedaan) merepresentasikan bentuk visual yang menunjukkan identitas dari pengguna tagar. Tagar ini didominasi oleh bentuk visual berupa foto diri atau selfie dari pengguna. Foto diri atau selfie ini digunakan oleh pengguna tagar sebagai bentuk representasi dirinya yang dilahirkan di tengah keberagaman suku, etnis, dan agama di Indonesia. Hal ini menunjukkan adanya relasi antara identitas pengguna tagar dengan representasi dirinya yang tergambar pada foto diri yang diunggahnya. Selain itu, relasi tersebut juga didukung dengan judul (caption) foto yang disertakan dalam pemberian tagar.

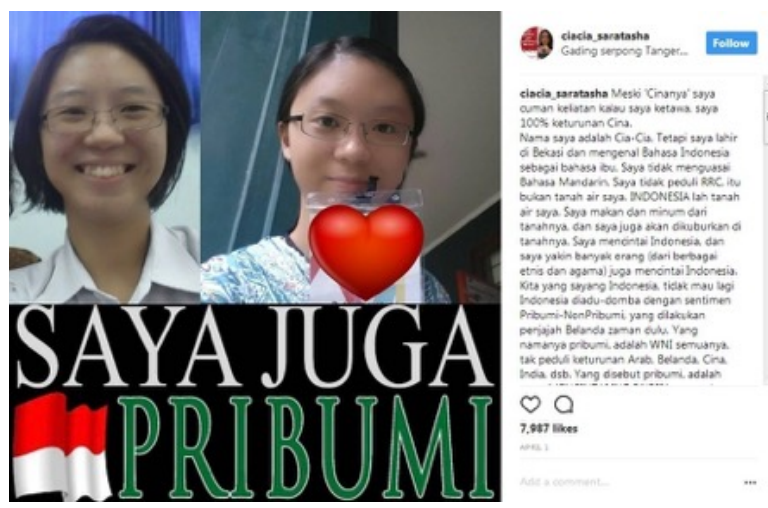

Gambar 5 Unggahan Patricia pada tanggal 1 April 2017 dengan menggunakan \#rayakanperbedaan (Sumber: www.Instagram.com/ciacia_saratasha/) 
2. Praktik Kewacanaan

Hingga awal Juni 2017, tagar ini telah diunggah sebanyak 1.807 unggahan. Produksi teks dari tagar ini mengandung sebuah ajakan untuk bersama-sama merayakan perbedaan suku, ras, dan agama tanpa membedabedakan satu dengan yang lainnya. Golongan yang berusaha 'dilawan' oleh tagar ini adalah kelompok masyarakat yang berusaha memecah belah persatuan bangsa melalui berbagai isu SARA.

Pada tahap konsumsi teks, dapat terlihat pada kolom komentar yang dilakukan oleh pengguna lain dalam memaknai bentuk teks, baik verbal maupun visual, yang diunggah oleh pengguna. Sehingga dapat terlihat bahwa wacana yang disampaikan oleh pengguna \#rayakanperbedaan dapat dimaknai berbeda oleh pengguna lain.

\section{Praktik Sosial}

Tagar rayakan perbedaan (\#rayakanperbedaan) diproduksi pertama kali pada tanggal $11 \mathrm{Mei}$
2017 saat akun @dirasugandi, $\mathrm{dkk}$, mengajak pengguna lain menggunakan tagar tersebut untuk merayakan keberagaman di lingkungan bermasyarakat melalui akun Instagram. Sama hal-nya dengan \#pekanpancasila, \#rayakanperbedaan

dilatarbelakangi oleh kondisi sosial dimana semangat kebhinekaan berusaha dirusak oleh kaum radikal yang menyudutkan suku, etnis, dan agam tertentu. Dapat dikatakan \#rayakanperbedaan dan \#pekanpancasila terbentuk pada kondisi sosial yang sama di mana situasi politik pada saat itu dihubungkan dengan isu-isu berbau SARA.

\section{KESIMPULAN}

Tagar dalam media sosial Instagram berfungsi sebagai sign system yang memberikan sebuah informasi terkait sebuah kejadian, peristiwa, atau fenomena tertentu. Berbagai informasi tersebut diarsipkan di dalam tagar sehingga dapat diakses oleh siapa saja yang terhubung ke dalam jaringan. Kemudahan akses dan penyebaran informasi melalui tagar tersebut, tak jarang membuat tagar digunakan sebagai alat untuk merespon sebuah kejadian, peristiwa, atau fenomena 
sosial yang sedang berkembang di masyarakat.

Setelah melakukan analisis terhadap dimensi teks, praktik kewacanaan, dan praktik sosial, dapat disimpulkan bahwa tagar dalam media sosial Instagram muncul sebagai trend masyarakat dalam merespon berbagai isu dan fenomena yang sedang berkembang. Respon ini dapat berupa sebuah bentuk dukungan, simpati, aksi solidaritas, maupun bentuk perlawanan dari masyarakat. Berbagai respon tersebut memunculkan adanya gerakan sosial dalam masyarakat yang terjadi melalui media sosial Instagram. Kekuasaan yang dimiliki oleh pengguna selaku produsen tagar dimanfaatkan untuk menciptakan suatu gerakan dalam merespon berbagai kondisi dan fenomena yang sedang/telah berlangsung di masyarakat. Adanya gerakan sosial ini lah yang kemudian diarsipkan ke dalam sebuah tagar agar informasi yang terkandung di dalamnya dapat dengan mudah diakses oleh siapa saja yang terhubung di dalam jaringan.

\section{DAFTAR PUSTAKA}

[1] Eriyanto. 2001. Analisis Wacana: Pengantar Analisis Teks Media. Yogyakarta: LkiS Yogyakarta

[2] Fairclogh, Norman. 1995. Critical Discourse Analysis: The Critical Study of Language. Harlow: Pearson.

[3] Haryatmoko. 2016. Critical Discourse Analysis (Analisis Wacana Kritis): Landasan Teori, Metodologi dan
Penerapan. Jakarta: RajaGrafindo Persada.

[4] Lull, James. 1998. Media Komunikasi Kebudayaan: Suatu Pendekatan Global. Penerjemah A. Setiawan Abadi. Jakarta: Yayasan Obor Indonesia.

[5] Nasrullah, Rulli. 2010. Komunikasi Antarbudaya di Era Budaya Siber. Jakarta: Kencana

[6] 2015. Media Sosial: Perspektif Komunikasi, Budaya, dan Sosioteknologi. Bandung: Simbiosa Rekatama Media.

\section{Sumber Pertautan :}

[1] Gareta, Sella Panduarsa. 2016. "Jumlah Terbaru Pengguna Internet di Dunia”. http://www.antaranews.com/berita/59763 8/jumlah-terbaru-pengguna-internet-didunia diakses tanggal 3 Mei 2017 pukul 21:30 WIB.

[2] Mahmud, Amirudin. 2016. "Kami Tidak Takut". http://www.kompasiana.com/amirudinm ahmud/kami-tidaktakut 569a14fae8afbd191497ecdc diakses tanggal 20 Maret 2017 pukul 14.45 WIB. 